\title{
Heroin-induced Conditioned Immunomodulation Requires Expression of IL-1 $\beta$ in the Dorsal Hippocampus
}

\author{
Jennifer L. Szczytkowski ${ }^{1,2}$, Christina Lebonville ${ }^{1}$, Lee Hutson ${ }^{1}$, Rita A. Fuchs ${ }^{1}$, and Donald \\ T. Lysle ${ }^{1, *}$ \\ ${ }^{1}$ University of North Carolina at Chapel Hill, Department of Psychology, CB\#3270, Chapel Hill, \\ NC 27599-3270 USA \\ ${ }^{2}$ Messiah College, Department of Psychology, One College Avenue Suite 3052, Mechanicsburg, \\ PA 17055 USA
}

\begin{abstract}
Opioid-associated environmental stimuli elicit robust immune-altering effects via stimulation of a neural circuitry that includes the basolateral amygdala and nucleus accumbens. These brain regions are known to have both direct and indirect connections with the hippocampus. Thus, the present study evaluated whether the dorsal hippocampus (DH), and more specifically interleukin-1 beta (IL-1 $\beta$ ) within the DH, is necessary for the expression of heroin-induced conditioned immunomodulation. Rats received five Pavlovian pairings of systemic heroin administration (1.0 $\mathrm{mg} / \mathrm{kg}, \mathrm{SC}$ ) with placement into a distinct environment (conditioned stimulus, CS). Six days after conditioning, a GABA $\mathrm{A}_{\mathrm{B}}$ agonist cocktail or IL- $1 \beta$ small interfering RNA (siRNA) was microinfused into the $\mathrm{DH}$ to inhibit neuronal activity or IL-1 $\beta$ gene expression prior to CS or home cage exposure. Control animals received saline or negative control siRNA microinfusions. Furthermore, all rats received systemic administration of lipopolysaccharide (LPS) to stimulate proinflammatory nitric oxide production. CS exposure suppressed LPS-induced nitric oxide production relative to home cage exposure. Inactivation of, or IL- $1 \beta$ silencing in, the DH disrupted the CS-induced suppression of nitric oxide production relative to vehicle or negative control siRNA treatment. These results are the first to show a role for DH IL- $1 \beta$ expression in heroinconditioned suppression of a proinflammatory immune response.
\end{abstract}

\section{Keywords \\ dorsal hippocampus; heroin; IL-1; conditioning; siRNA; nitric oxide}

\section{Introduction}

Opioids exert a number of detrimental physiological effects, including disruption of immune system functioning, that diminish host defense mechanisms and increase susceptibility to infectious disease states (Simonovska et al., 2011). For instance, acute heroin administration results in the suppression of the peripheral proinflammatory mediator inducible nitric oxide synthase (iNOS), the enzyme that is responsible for nitric oxide production (Lysle and How,

\footnotetext{
(C) 2013 Elsevier Inc. All rights reserved.

*Corresponding Author: dlysle@email.unc.edu, Telephone: +1-919-537-3748 Fax: +1-919-962-2537.

Publisher's Disclaimer: This is a PDF file of an unedited manuscript that has been accepted for publication. As a service to our customers we are providing this early version of the manuscript. The manuscript will undergo copyediting, typesetting, and review of the resulting proof before it is published in its final citable form. Please note that during the production process errors may be discovered which could affect the content, and all legal disclaimers that apply to the journal pertain.
} 
2000). Nitric oxide production by immune cells, particularly macrophages, alters the course of microbial resistance and autoimmune diseases (Breitbach et al., 2006; Choi et al., 2006; Green et al., 1990; Green et al., 1993; MacMicking et al., 1995; Murray and Nathan, 1999; Oates and Gilkeson, 2006; Rossi et al., 1999; Stofkova et al., 2006; Vincendeau et al., 1992; Wei et al., 1995), provides resistance to viral infections and exerts significant tumor cytotoxicity (Green et al., 1993; Hibbs et al., 1987; Hrabak et al., 2006; Karupiah et al., 1993). Moreover, mice lacking the gene for iNOS exhibit increased susceptibility to parasitic and bacterial infections (Lindgren et al., 2004; Wei et al., 1995), suggesting that iNOS acts as an antimicrobial agent. In addition, nitric oxide has numerous immunoregulatory functions, including the modulation of cytokine production (Marcinkiewicz and Chain, 1993; Taylor-Robinson et al., 1994; Van Dervort et al., 1994) and the suppression of lymphocyte proliferation (Albina and Henry, 1991). Thus, iNOS plays a critical role in immune function and heroin-induced suppression of nitric oxide likely increases susceptibility to infection following heroin administration.

Opioid-induced suppression of nitric oxide and other immune parameters are mediated by central nervous system (CNS) mechanisms. Consistent with this, central administration of the opioid antagonist, N-methylnaltrexone (a form of naltrexone which does not readily penetrate the blood-brain barrier), attenuates the immunomodulatory effects of systemic morphine treatment, whereas peripheral administration of $\mathrm{N}$-methylnaltrexone is ineffective (Fecho et al., 1996; Lysle et al., 1996). Furthermore, microinjection of morphine directly into the periaqueductal gray, a brain region rich in opioid receptors, suppresses natural killer (NK) cell cytotoxicity, an effect that can be blocked by peripheral administration of the opioid antagonist naltrexone (Weber and Pert, 1989). Interestingly, following repeated pairing with opioids, environmental stimuli can acquire the ability to induce alterations in immune function similar to those produced by the drug itself (Coussons-Read et al., 1994a, b; Coussons et al., 1992; Luecken and Lysle, 1992; Lysle et al., 1988; Lysle and Ijames, 2002; Szczytkowski et al., 2011; Szczytkowski and Lysle, 2007, 2008, 2010). These effects are the result of Pavlovian conditioning, and research in our laboratory has identified the basolateral amygdala (BLA) and the nucleus accumbens (NAC) as two brain regions necessary for opioid-induced condition immunomodulation (Saurer et al., 2009; Szczytkowski and Lysle, 2008). In support of this, $D_{1}$ dopamine receptor antagonism in the BLA inhibits conditioned decreases in the production of proinflammatory mediators in peripheral immune tissues (Szczytkowski and Lysle, 2010). More recently, our laboratory has shown that the integrity of a specific limbic neurocircuitry comprised of the BLA, NAC, and ventral tegmental area (VTA) is required for heroin-conditioned immunosuppression $(* * * * * * * *$ Szczytkowski et al., 2011). Each of these brain regions has anatomical connections with the hippocampus indicating the possibility that the hippocampus may also play a role in conditioned immune alterations.

The hippocampus is a heterogeneous structure with compartmentalized functionality and connectivity. In particular, the dorsal hippocampus (DH) is necessary for declarative, spatial, and configural learning and memory as well as for "contextual-recall," a form of memory that is dependent upon environmental cues (Maren and Holt, 1999; Phillips and Ledoux, 1994; Redish, 2001). Thus, following heroin conditioning, the DH likely provides crucial information about drug-associated environmental stimuli and facilitates conditioned immunomodulation. Furthermore, interaction between the BLA and the DH is necessary for the expression of context-induced drug-seeking behavior (Fuchs et al., 2005). As a regulator of a number of conditioning processes, the DH appears to be a likely component of the neural circuitry of heroin-induced conditioned immunomodulation. Accordingly, Experiment 1 in the present study utilized GABA agonist-induced temporary inactivation of the $\mathrm{DH}$ in order to investigate the hypothesis that the functional integrity of the $\mathrm{DH}$ is required for the expression of heroin-induced conditioned immunosuppression. 
The second aim of the present study was to assess the role of the cytokine, interleukin- 1 beta (IL-1 $\beta$ ), in the DH in heroin-induced conditioned immunosuppression. IL-1 $\beta$ is expressed by glia and neurons in several regions of the brain including the hippocampus (McPherson et al., 2011; Rothwell, 1991). Once viewed primarily as immune molecules that mediate inflammatory events during pathology, cytokines are now recognized to be important regulators of neuronal communication similar in action to neurotransmitters and neuropeptides (Adler et al., 2005). Surprisingly little is known about brain cytokine function; however, emerging research suggests that IL- $1 \beta$ is essential for a number of behavioral processes, including learning and memory. For example, deletion of the IL-1 receptor type 1 (IL-1R1) gene results in impaired hippocampal-dependent learning and memory function (Avital et al., 2003; Ben Menachem-Zidon et al., 2011; Goshen et al., 2007; Schmid et al., 2009). Conversely, Pavlovian fear conditioning is associated with increased IL-1 gene expression within the hippocampus (Goshen et al., 2007). Together, these results suggest that optimal levels of IL- $1 \beta$ are required for proper hippocampal function and memory processing, however, the role of hippocampal IL- $1 \beta$ in conditioned immunomodulation has not yet been investigated. Thus, Experiment 2 in the present study utilized small interfering RNA (siRNA) mediated IL-1 $\beta$ RNA interference in order to test the hypothesis that IL-1 $\beta$ activity in the DH is necessary for the expression of heroininduced conditioned immunosuppression.

\section{Methods and Materials}

\section{Animals}

Male Lewis rats (Charles-River Laboratories), weighing 225-250 g, were housed individually in a colony room under a reversed 12-hour day-night cycle, with free access to food and water. Animals received a 2-week habituation period before experimentation and were handled regularly during this time. All procedures were approved by the Institutional Animal Care and Use Committee (IACUC) of the University of North Carolina at Chapel Hill and conformed to the National Research Council's Guide for the Care and Use of Laboratory Animals (Institute of Laboratory Animal Resources on Life Sciences).

\section{Surgical Procedures}

Animals were anesthetized with a $1.0 \mathrm{ml} / \mathrm{kg}$ intraperitoneal injection of 9:1 (vol:vol) ketamine hydrochloride $(100 \mathrm{mg} / \mathrm{ml})$ mixed with xylazine $(100 \mathrm{mg} / \mathrm{ml})$ and were placed into the stereotaxic apparatus. Guide cannula (26-gauge, Plastics One, Roanoke, VA) were directed bilaterally toward the DH (AP $-3.4 \mathrm{~mm}, \mathrm{ML} \pm 3.1 \mathrm{~mm}, \mathrm{DV} \mathrm{s} ; 2.15 \mathrm{~mm}$, relative to Bregma; $15^{\circ}$ angle laterally; (Paxinos and Watson, 1998). Animals were given two weeks for post-operative recovery.

\section{Conditioning Procedure}

Based on our prior studies (Szczytkowski et al., 2011; Szczytkowski and Lysle, 2010), rats received five, 60 min conditioning sessions. Each session involved heroin administration (diacetylmorphine dissolved in $0.9 \%$ sterile saline; NIDA Drug Supply System, Bethesda, MD) immediately followed by placement into a conditioning chamber (BRS/LVE, Laurel, MD, USA; $26.7 \times 24.8 \times 30.7$ ) that served as the conditioned stimulus (CS). A $1.0 \mathrm{mg} / \mathrm{kg}$ subcutaneous dose of heroin was selected based on prior experiments in our laboratory showing that this dosage alters LPS-induced iNOS mRNA expression in the spleen (Lysle and How, 2000; Lysle and Ijames, 2002; Szczytkowski and Lysle, 2007). The conditioning chambers were located in a room separate from the animal colony and contained a metal grid floor and cedar bedding to create an environment distinct from the home cage. Six days after conditioning, the rats were re-exposed to the conditioning chamber (CS) or remained in their home cages (HC) for $60 \mathrm{~min}$. Immediately thereafter, rats received a subcutaneous 
injection of LPS ( $1 \mu \mathrm{g} / \mathrm{kg}$; serotype $055: \mathrm{B} 5$, dissolved in sterile, pyrogen-free saline) to induce in vivo production of nitric oxide. Rats were sacrificed $6 \mathrm{~h}$ later and a sample of spleen and blood were obtained for the analysis of nitric oxide.

Prior work utilized a number of conditioning control groups to show systematically that the conditioned effects observed in this paradigm are due to context exposure itself as opposed to ancillary effects of the conditioning procedure. These control groups included a salineconditioned group that received saline injections paired with placement into the conditioning chamber and an unpaired heroin-treated group that was conditioned with saline and received heroin injections outside of the conditioning context (Lysle and Ijames, 2002). To conserve animals, these negative control groups were not included in the present study.

\section{Neuronal Inactivation}

In Experiment 1, rats received bilateral intra-DH microinfusions $(0.3 \mu 1 /$ hemisphere infused over $1 \mathrm{~min})$ of saline vehicle or a cocktail of baclofen and muscimol $(0.3 \mathrm{nmol}$ and 0.03 nmol, respectively) $30 \mathrm{~min}$ prior to $\mathrm{CS}$ or home cage exposure on the test day. This combination of $\mathrm{GABA}_{\mathrm{B}}$ and $\mathrm{GABA}_{\mathrm{A}}$ agonists has been used extensively to transiently disrupt neural activity in cell bodies within target brain regions, including the $\mathrm{DH}$, without affecting fibers of passage (Fuchs et al., 2007; Lasseter et al., 2011; Szczytkowski and Lysle, 2008).

Injectors extended $2 \mathrm{~mm}$ beyond the tip of the guide cannula and were left in place for 1 minute after the injection to allow for proper diffusion away from the infusion site. Prior experiments from our laboratory have shown no effect of inactivation of an anatomical control region, the somatosensory cortex, that is located just dorsal relative to the $\mathrm{DH}$, on drug context- induced goal-directed behavior (Fuchs et al., 2005; Ramirez et al., 2009).

\section{IL-1 $\beta$ silencing}

For the siRNA experiment (Experiment 2) and verification (Experiment 3), rats received intracranial microinfusions of negative control or IL- $1 \beta$ siRNA (both $5.6 \mathrm{pmol} / 0.7 \mu \mathrm{l} /$ hemisphere) into the $\mathrm{DH} 48 \mathrm{~h}$ prior to the test session in order to maximize IL- $1 \beta$ knockdown at the time of testing. Following the infusion $(0.23 \mu \mathrm{l} / \mathrm{min})$, injectors were left in place for $5 \mathrm{~min}$. The procedure utilized three sets of siRNA designed to the rat IL- $1 \beta$ mRNA sequence (NCBI Accession number: NM_031512.2) using Invitrogen's BLOCK-iT ${ }^{\mathrm{tm}} \mathrm{RNAi}$ Express tool (Invitrogen; Pre-designed Stealth Select siRNA, HPLC purity). The sense sequences of the IL-1 $\beta$ siRNA were $5^{\prime}$-CCAAAGUGGAGUUUGAGUCUGCACA-3', $5^{\prime}$ UUGUUCAUCUCGAAGCCUGCAGUGC- ${ }^{\prime}$, and $5^{\prime}-$

ACUGUCCCUGAACUCAACUGUGAAA- ${ }^{\prime}$, with the corresponding antisense sequences $5^{\prime}$-UGUGCAGACUCAAACUCCACUUUGG-3', 5' GCACUGCAGGCUUCGAGAUGAACAA- $3^{\prime}$, and $5^{\prime}$ UUUCACAGUUGAGUUCAGGGACAGU- ${ }^{\prime}$, respectively. Multiple siRNA duplexes were transfected to target different segments of the intended mRNA sequence, thereby maximizing knock down efficiency (Chao et al., 2011). Additionally, two different sets of missense negative control siRNA (Invitrogen; Med and Lo GC Negative Controls, HPLC purity) were used that complemented the GC content of the IL- $1 \beta$ siRNAs. The sense sequences used were $5^{\prime}$-AGCUACACUAUCGAGCAAUUAACUU- $3^{\prime}, 5^{\prime}$ UUCCUCUCCACGCGCAGUACAUUUA- $3^{\prime}$ and the corresponding antisense sequences, $5^{\prime}$-AAGUUAAUUGCUCGAUAGUGUAGCU-3' ${ }^{\prime}$ and $5^{\prime}-$ UAAAUGUACUGCGCGUGGAGAGGAA- ${ }^{\prime}$. All siRNA was complexed with jetSI ${ }^{\text {tm }}$ (Polyplus Transfection Illkirch, Cat\# 403-05), a cationic lipid transfection agent that facilitates transfection into brain tissue in vivo, according to the manufacturer's protocol. 


\section{Real-time qRT-PCR}

To determine iNOS mRNA expression, real-time qRT-PCR was performed on tissue samples from the spleen. The spleen was analyzed because immunohistochemical localization of iNOS in rats exposed to LPS shows the presence of the iNOS enzyme in a number of immune cells found in the spleen, including macrophages, lymphocytes, and neutrophils (Bandaletova et al., 1993). Total RNA was extracted using TRI-Reagent (Molecular Research Center, Cincinnati, OH), a modification of the original method described by Chomczynski and Sacchi (Chomczynski and Sacchi, 1987). RNA was quantified spectrophotometrically (GeneQuant II, Pharmacia-Biotech, Piscataway, NJ, USA). Reverse transcription was performed using Oligo(dT) 18 primer and Moloney Murine Leukemia Virus-Reverse transcriptase following the protocol of the Advantage RT-for-PCR Kit from Clontech (Palo Alto, CA, USA). Specific products from the PCR reaction were detected with Universal ProbeLibrary Probes (Roche, Indianapolis, IN). PCR amplifications were performed using standard protocols, the LightCycler TaqMan Master Real-Time PCR Kit and the LightCycler II instrument (Roche, Indianapolis, IN). A master mix containing all reaction components was prepared and then $20 \mu \mathrm{l}$ of cDNA with master mix was placed in glass capillary tubes specifically designed for use in the LightCycler II system. Primers and probes for iNOS were as follows: $5^{\prime}$-TGAGGATTACTTCTTCCAGCTCA-3' and $5^{\prime}$ TGGGTGTCAGAGTCTTGTGC-3' ${ }^{\prime}$, using probe \#25. Primers were synthesized by the Nucleic Acids Core Facility (Lineberger Cancer Center, UNC-Chapel Hill). Copy numbers were generated based on an internal standard curve. Amplifications were carried out for 45 cycles and curves showing fluorescence at each cycle were determined by the computer software (Roche). Samples were pre-incubated for $10 \mathrm{~min}$ at $95^{\circ} \mathrm{C}$ to activate the Fast-Start Taq DNA polymerase. The cycle temperatures were 95 and $60^{\circ} \mathrm{C}$ and the cycle times were 10 and $30 \mathrm{~s}$ for the denaturing and annealing/extending, respectively. Fluorescence level was determined at the end of the extending phase for each cycle of PCR. A final cooling phase was carried out at $40^{\circ} \mathrm{C}$ for $30 \mathrm{~s}$. The analysis of the fluorescence in standards and samples over the course of 45 cycles was used to derive the number of copies of the target molecule in each sample. Additionally, assessments of housekeeping gene expression, L13A, were made to verify comparable RNA quality across samples. L13A primers were $5^{\prime}$ CCCTCCACCCTATGACAAGA-3' and $5^{\prime}$-GGTACTTCCACCCGACCTC- $3^{\prime}$, with probe \#74. The data are expressed as iNOS copies per $10 \mathrm{ng}$ cDNA based on a standard curve using Roche LightCycler software.

\section{Nitrite/nitrate assay}

The nitrite/nitrate concentration in plasma samples was assessed using the Greiss reagent assay as described previously (Szczytkowski and Lysle, 2007). Briefly, $6 \mu 1$ of plasma diluted in $44 \mu \mathrm{l}$ of $\mathrm{dH} 2 \mathrm{O}$ was incubated in the dark for 90 min with $10 \mu \mathrm{l}$ of nitrate reductase $(1.0 \mathrm{U} / \mathrm{ml}), 20 \mu \mathrm{l}$ of $0.31 \mathrm{M}$ phosphate buffer $(\mathrm{pH} 7.5), 10 \mu \mathrm{l}$ of $0.86 \mathrm{mM} \mathrm{NADPH}$ (Sigma) and $10 \mu \mathrm{l}$ of $0.11 \mathrm{mM}$ flavin adenine dinucleotide in individual wells of a 96-well plate. Then, $200 \mathrm{ml}$ of Greiss reagent, consisting of a 1:1 (v/v) solution $1 \%$ sulfanilamide in $5.0 \%$ phosphoric acid and $0.1 \% \mathrm{~N}$-(1-napthyl) ethyl-enedamine dihydrochloride in distilled water, was added to the samples. The color developed for $10 \mathrm{~min}$ at room temperature, after which, the absorbance was determined using a spectrophotometer set at $550 \mathrm{~nm}$. All reactions were carried out in triplicate. The total micromolar concentration of nitrite was determined for each sample based on a standard curve. Recovery of nitrate is greater than $95 \%$ using this assay.

\section{Histology}

To confirm proper cannula placement, Alcian blue dye was infused via the cannulae following euthanasia. Brains were then extracted and post-fixed in a $4 \%$ paraformaldehyde solution. Following fixation, the brains were transferred to $30 \%$ sucrose solution for 
cryoprotection. Coronal sections $(50 \mu \mathrm{m})$ were taken and stained with cresyl violet for verification of cannula placement using light microscopy.

\section{Verification of siRNA effectiveness}

The effectiveness of the intra-DH siRNA manipulation in inhibiting IL- $1 \beta$ expression was validated in a separate group of rats. These rats received bilateral IL- $1 \beta$ siRNA or negative control microinfusions into the DH using the infusion parameters as employed in experiment 2 , followed $48 \mathrm{~h}$ later by systemic LPS administration $(1.0 \mathrm{mg} / \mathrm{kg})$ to induce hippocampal IL- $1 \beta$ expression. The DH was harvested for real-time qRT-PCR analysis of IL- $1 \beta$ and L13A (housekeeping gene) expression $4 \mathrm{~h}$ after LPS administration, as described previously. Primers and probes for IL- $1 \beta$ were as follows: $5^{\prime}$-AGCTTCAGGAAGGCAGTGTC- $3^{\prime}$ and $5^{\prime}$-TCCCACGAGTCACAGAGGA-3', using probe \#5. The data are expressed as IL-1 $\beta$ copies per 10 ng cDNA based on a standard curve using Roche LightCycler software.

\section{Statistical analysis}

Analyses of variance (ANOVAs) or Student's t-tests were performed on the data sets, when appropriate. For all experiments, the significance level was set at 0.05 . The source of significant omnibus ANOVA effects was examined using Tukey's post-hoc test.

\section{Results}

Experiment 1 investigated the effect of bilateral DH inactivation on the expression of heroin-induced conditioned suppression of inducible nitric oxide synthase (iNOS), an important peripheral proinflammatory mediator, in the spleen (Hibbs et al., 1987; Vincendeau et al., 1992; Wei et al., 1995). Cannula placements were located bilaterally in the DH (Figure 1). Rats received five Pavlovian conditioning trials during which a distinct environment (conditioned stimulus, CS) was paired with systemic heroin administration. Six days after conditioning, a test session was conducted during which the rats were re-exposed to the previously heroin-paired environment (CS Exposed) or remained in their home cages $(\mathrm{HC})$ for $60 \mathrm{~min}$. $\mathrm{A} \mathrm{GABA}_{\mathrm{B}} / \mathrm{GABA}_{\mathrm{A}}$ agonist cocktail (muscimol and baclofen, B/M; $0.3 / 0.03 \mathrm{nmol} ; 0.3 \mu \mathrm{l} / \mathrm{hemisphere)}$ or saline was microinfused into the $\mathrm{DH} 30 \mathrm{~min}$ prior to the test session. Lipopolysaccharide (LPS, $1.0 \mathrm{mg} / \mathrm{kg}$, SC) was administered immediately after testing in order to induce nitric oxide production. Two indices of nitric oxide production, iNOS mRNA expression in the spleen and nitrite/nitrate levels in blood plasma, were assessed.

GABA agonist-induced neural inactivation of the DH inhibited the heroin-conditioned suppression of iNOS mRNA in the spleen (Figure 2A). The omnibus ANOVA revealed a difference between the four groups in LPS-induced iNOS copies $[F(3,17)=3.68, P<0.05]$. Pairwise comparisons indicated that, following intra-DH saline pretreatment, splenic iNOS mRNA expression was decreased upon exposure to the previously heroin-paired environment relative to remaining in the home cage (Tukey test, $P=0.028$ ). Importantly, following intra-DH B/M pretreatment, splenic iNOS mRNA expression did not differ between the CS exposed and the home cage groups. There was no significant alteration in housekeeping gene (L13A) expression between the groups (data not shown). Thus, B/M treatment abolished the heroin-induced conditioned suppression in splenic iNOS mRNA expression.

GABA agonist-induced neural inactivation of the DH also impaired heroin-induced conditioned suppression of plasma nitrite/nitrate levels (Figure 2B). The omnibus ANOVA revealed a difference between the four groups in plasma nitrite/nitrate levels $[F(3,17)=$ $4.362, P<0.05]$. Pair-wise comparisons indicated that plasma nitrite/nitrate concentration 
was decreased upon exposure to the previously heroin-paired environment relative to remaining in the home cage (Tukey test, $P=0.011$ ), consistent with the iNOS mRNA expression data. Conversely, following $\mathrm{B} / \mathrm{M}$ pretreatment, plasma nitrite/nitrate concentration did not differ upon exposure to the CS. Thus, B/M treatment disrupted the heroin-conditioned reduction in plasma nitrite/nitrate concentration.

Experiment 2 investigated the role of DH interleukin-1 beta (IL-1 $\beta$ ) in heroin-induced conditioned suppression of peripheral proinflammatory mediators. As in Experiment 1, cannula placements were located bilaterally within the DH (Figure 3). The experimental procedures were the same as in Experiment 1 except that animals received intra-DH microinfusions of negative control (missense) or IL- $1 \beta$ small interfering RNA (siRNA; both $5.6 \mathrm{pmol} / 0.7 \mu \mathrm{l} / \mathrm{hemisphere)} 48 \mathrm{~h}$ prior to exposure to the previously heroin-paired context or the home cage.

siRNA-induced IL- $1 \beta$ RNA interference in the DH disrupted heroin-conditioned suppression of iNOS in the spleen (Figure 4A). The omnibus ANOVA for iNOS copies revealed a difference between the groups $[F(3,19)=4.95, P<0.05]$. Pair-wise comparisons indicated that, following negative control pretreatment in the DH, splenic iNOS mRNA copies were decreased upon exposure to the previously heroin-paired environment compared to remaining in the home cage (Tukey test, $P=0.046$ ). In contrast, following intra-DH IL-1 $\beta$ sense siRNA pretreatment, splenic iNOS mRNA expression did not differ upon exposure to the CS. There was no significant alteration in housekeeping gene (L13A) expression in the groups (data not shown). Thus, IL- $1 \beta$ siRNA pretreatment disrupted the heroin-conditioned reduction in splenic iNOS mRNA expression.

IL-1 $\beta$ RNA interference in the DH also inhibited the heroin-induced conditioned suppression of plasma nitrite/nitrate levels (Figure 4B). The omnibus ANOVA for plasma nitrite/nitrate levels revealed a difference between the groups $[F(3,19)=6.07, P<0.05]$. Pairwise comparisons indicated that, following negative control pretreatment in the $\mathrm{DH}$, plasma nitrite/nitrate levels were decreased upon exposure to the previously heroin-paired environment compared to remaining in the home cage (Tukey test, $P=0.024$ ). In contrast, following intra-DH IL-1 $\beta$ siRNA pretreatment, plasma nitrite/nitrate concentration did not differ upon exposure to the CS. Thus, IL-1 $\beta$ siRNA pretreatment disrupted the heroinconditioned reduction in plasma nitrite/nitrate levels.

The effectiveness of the intra-DH siRNA manipulation in blocking IL-1 $\beta$ expression in the DH was validated in a separate group of rats (Figure 5). These rats received bilateral IL-1 $\beta$ siRNA or negative control microinfusions into the DH using the infusion parameters employed in Experiment 2, followed $48 \mathrm{~h}$ later by systemic LPS administration to induce hippocampal IL-1 $\beta$ expression. The DH was harvested for real-time qRT-PCR analysis of IL- $1 \beta$ expression $4 \mathrm{~h}$ after LPS administration. Intra-DH administration of IL- $1 \beta$ siRNA decreased IL- $1 \beta$ copies in the DH relative to negative control administration $[t(6)=3.516$; $P<0.05]$. There was no significant alteration in housekeeping gene (L13A) expression in the groups (data not shown). Thus, intra-DH IL- $1 \beta$ siRNA pretreatment blocked the expression of LPS-induced IL- $1 \beta$ in the DH.

\section{Discussion}

In the present study, both global neural inactivation of the dorsal hippocampus (DH) and interleukin-1 beta (IL-1 $\beta$ ) RNA interference within the DH impaired the ability of a heroinpaired environment to suppress splenic iNOS mRNA expression and plasma nitrite/nitrate levels, thereby rescuing nitric oxide production. Previous reports from our laboratory have elucidated key brain regions and identified critical neural circuitry necessary for the 
expression of heroin-induced conditioned immunomodulation. The results of the current set of experiments significantly expand this line of research by revealing the $\mathrm{DH}$ as another necessary component of the neural circuitry mediating heroin-induced conditioned immunomodulation. Furthermore, the results also reveal that IL-1 $\beta$-mediated processes within the DH mediate the conditioned suppression of LPS-induced nitric oxide production.

Nitric oxide is essential for the body's defense against infectious challenge as its induction is associated with protection against numerous pathogens, including bacteria, fungi, parasites, and viruses (Liew, 1994; Tsai et al., 1997). Bacterial infections associated with injection drug use account for more than one-third of drug-related hospital admissions and can quickly progress to major systemic infection and cause severe damage to organs such as the heart and lungs (Orangio et al., 1984; White, 1973). Since heroin use is associated with a high incidence of opportunistic infections (Hussey and Katz, 1950; Louria et al., 1967; Luttgens, 1949; Theodorou and Haber, 2005) and both heroin administration and exposure to heroin-associated cues significantly reduce LPS-induced iNOS expression (Lysle and How, 2000; Lysle and Ijames, 2002), drug-induced and drug-conditioned reductions in nitric oxide production may be involved in this increased incidence of infectious disease. Thus, the finding that these conditioned reductions in nitric oxide are mediated by IL- $1 \beta$ signaling in the DH provides an important public health perspective. While the focus of the current study was on splenic iNOS expression, it is likely that other immune parameters may also be subject to alteration by inactivation or IL-1 $\beta$ suppression within the hippocampus. Previous research from our laboratory has shown that inactivation of other key brain regions (i.e., the BLA and NAC) attenuates conditioned immunomodulation across several immune parameters, including peripheral expression of the cytokines TNF- $a$, IL-6 and IL-1 (Szczytkowski et al., 2011; Szczytkowski and Lysle, 2008).

The results of Experiment 1 in the present study demonstrate that the functional integrity of the DH is necessary for conditioned immunomodulation. Temporary inactivation of the DH blocked heroin conditioned suppression of LPS-induced nitric oxide production. The DH is somewhat isolated from adjacent brain regions as it is surrounded by the lateral ventricle. Furthermore, temporary neural inactivation of the dorsally overlying trunk region of the somatosensory cortex, the brain region most likely in the path of inadvertent $\mathrm{B} / \mathrm{M}$ infusion away from the DH, fails to alter drug-induced conditioned behaviors, such as drug contextinduced cocaine seeking (Fuchs et al., 2005). This suggests that the intracranial manipulations in the present study were anatomically selective to the DH and not due to B/ $\mathrm{M}$ diffusion to dorsal brain regions.

Previous reports from our laboratory have identified the basolateral amygdala (BLA), nucleus accumbens (NAC), and ventral tegmental area (VTA) as responsible for mediating conditioned immunomodulation (Szczytkowski et al., 2011). These brain regions are extensively connected to one another and to the $\mathrm{DH}$, providing anatomical basis for a putative neural circuitry (Del-Fava et al., 2007; Ikemoto, 2007; Mcdonald, 1991). In support of this, interaction between the DH and BLA is necessary for a cocaine-paired context to induce drug-seeking behavior (Fuchs et al., 2005). Based on its well-known involvement in spatial learning and memory (Fanselow and Dong, 2010), it is likely that the DH contributes to heroin-induced conditioned immunomodulation within this circuitry by facilitating the acquisition and expression of contextual associations.

Immune molecules, such as cytokines, can regulate neural processes including learning and memory consolidation. IL- $1 \beta$ has been shown to critically mediate hippocampal-dependent learning via the stimulation of IL-1 receptor type 1 (IL-1R1). IL-1 receptor antagonism disrupts long-term potentiation (LTP), and mice lacking IL-1 $\beta$ or the IL-1R1 exhibit severe memory deficits in hippocampal-dependent learning (Ben Menachem-Zidon et al., 2011; 
Goshen et al., 2007; Ross et al., 2003; Schneider et al., 1998). However, pathophysiologically high levels of IL-1 $\beta$, such as those observed following infection or injury, are also disruptive to learning and memory processes and have been associated with cognitive impairment in Alzheimer's disease and Down Syndrome (Griffin et al., 1989). In the current study, IL-1 $\beta$ RNA interference in the DH prevented peripheral immunosuppression by the heroin-paired context. These results show that, similar to other forms of learning, Pavlovian conditioned immunosuppression requires optimal levels of IL-1 $\beta$ within the hippocampus and that impaired IL-1 signaling blocks the expression of the conditioned effect. Additional studies would have to determine whether this effect is related to interference with memory retrieval processes that are utilized during reexposure to the CS or block effector processes necessary for peripheral immune modulation.

The cellular effects of IL- $1 \beta$ are cell specific within the hippocampus. Within the DH, several cell types are capable of producing IL- $1 \beta$, and both neurons and glia express IL-1 receptors (Yabuuchi et al., 1994; Zhang et al., 2010). In astrocytes, IL-1 $\beta$ initiates the formation of IL-1 $\beta$ signaling intermediates, such as interleukin-1 receptor-associated kinase (IRAK; (Flannery and Bowie, 2010; Ringwood and Li, 2008) and the subsequent activation of p38, extracellular signal-regulated kinase (ERK) and nuclear factor kappa-light-chainenhancer of activated B cells (NFkB;(Guasch et al., 2007; Huang et al., 2011). Conversely, in hippocampal neurons, IL-1 $\beta$ activates p38 and ERK, but not NFkB (Huang et al., 2011). In addition to IRAK-mediated mechanisms, ERK activation can occur via the IL-1R1mediated activation of Src family tyrosine kinases and N-methyl-D-aspartic acid (NMDA) glutamate receptor-mediated signaling cascades (Bertotto et al., 2011; Davis et al., 2006; Tsakiri et al., 2008; Viviani et al., 2003). Once activated, ERK and p38 translocate into the nucleus and initiate the transcription of immediate-early genes (e.g., c-Fos, c-Jun) and IL-1 $\beta$ responsive genes and facilitate the stabilization of these transcripts (Weber et al., 2010; Zhang et al., 2010). Furthermore, NFkB and the mitogen-activated protein kinase, c-Jun Nterminal kinase (JNK), may be important in immunomodulation via their effects on hypothalamic-pituitary-adrenal (HPA) axis function. Complex interactions between cell types and multiple signaling cascades likely gives rise to a nuanced control over immune function by IL- $1 \beta$. Thus, future studies will need to characterize the phenotype of DH cells that produce or respond to IL- $1 \beta$ and the IL- $1 \beta$-mediated intracellular signaling pathways that control heroin-induced conditioned immunosuppression.

Overall, the results reported here indicate that IL- $1 \beta$ within the DH plays a critical role in heroin-induced conditioned immunomodulation. Given that conditioned immunosuppression is a drug-like conditioned effect, heroin may also elicit immunosuppression in an IL-1 $\beta$ dependent fashion. However, the DH may be uniquely critical for the integration of contextual information for conditioned, but not for the unconditioned, heroin effects. Future comparisons between the role of IL- $1 \beta$ in conditioned and unconditioned immunosuppression will therefore enhance our understanding of each phenomenon. Meanwhile, the results of the present study identify a mechanism by which nitric oxide, a molecule critical for proper immune functioning, can be inhibited following exposure to previously heroin-paired environmental stimuli and suggest that IL- $1 \beta$ may be a target for the development of pharmacotherapies that restore immune function in former and current opioid users.

\section{Acknowledgments}

This research was supported by National Institute on Drug Abuse grant DA25667. JLS was supported by the Seeding Postdoctoral Innovators in Research and Education (SPIRE) program funded by the National Institutes of Health, Training, Workforce Development, and Diversity division of the National Institute of General Medical Sciences (NIGMS) grant K12GM000678. 


\section{References}

Adler MW, Geller EB, Chen XH, Rogers TJ. Viewing chemokines as a third major system of communication in the brain. Aaps Journal. 2005; 7:E865-E870. [PubMed: 16594639]

Albina JE, Henry WL Jr. Suppression of lymphocyte proliferation through the nitric oxide synthesizing pathway. The Journal of surgical research. 1991; 50:403-409. [PubMed: 2020192]

Avital A, Goshen I, Kamsler A, Segal M, Iverfeldt K, Richter-Levin G, Yirmiya R. Impaired interleukin-1 signaling is associated with deficits in hippocampal memory processes and neural plasticity. Hippocampus. 2003; 13:826-834. [PubMed: 14620878]

Bandaletova T, Brouet I, Bartsch H, Sugimura T, Esumi H, Ohshima H. Immunohistochemical localization of an inducible form of nitric oxide synthase in various organs of rats treated with Propionibacterium acnes and lipopolysaccharide. APMIS: acta pathologica, microbiologica, et immunologica Scandinavica. 1993; 101:330-336.

Ben Menachem-Zidon O, Avital A, Ben-Menahem Y, Goshen I, Kreisel T, Shmueli EM, Segal M, Ben Hur T, Yirmiya R. Astrocytes support hippocampal-dependent memory and long-term potentiation via interleukin-1 signaling. Brain, behavior, and immunity. 2011; 25:1008-1016.

Bertotto ME, Maldonado NM, Bignante EA, Gorosito SV, Cambiasso MJ, Molina VA, Martijena ID. Erk activation in the amygdala and hippocampus induced by fear conditioning in ethanol withdrawn rats: Modulation by mk-801. Eur Neuropsychopharm. 2011; 21:892-904.

Breitbach K, Klocke S, Tschernig T, van Rooijen N, Baumann U, Steinmetz I. Role of inducible nitric oxide synthase and NADPH oxidase in early control of Burkholderia pseudomallei infection in mice. Infection and immunity. 2006; 74:6300-6309. [PubMed: 17000727]

Chao CC, Ma YL, Lee EH. Brain-derived neurotrophic factor enhances Bcl-xL expression through protein kinase casein kinase 2-activated and nuclear factor kappa B-mediated pathway in rat hippocampus. Brain Pathol. 2011; 21:150-162. [PubMed: 20731656]

Choi J, Hoffman LA, Rodway GW, Sethi JM. Markers of lung disease in exhaled breath: nitric oxide. Biological research for nursing. 2006; 7:241-255. [PubMed: 16581895]

Chomczynski P, Sacchi N. Single-step method of RNA isolation by acid guanidinium thiocyanatephenol-chloroform extraction. Analytical biochemistry. 1987; 162:156-159. [PubMed: 2440339]

Coussons-Read ME, Dykstra LA, Lysle DT. Pavlovian conditioning of morphine-induced alterations of immune status: evidence for opioid receptor involvement. Journal of neuroimmunology. 1994a; 55:135-142. [PubMed: 7829663]

Coussons-Read ME, Dykstra LA, Lysle DT. Pavlovian conditioning of morphine-induced alterations of immune status: evidence for peripheral beta-adrenergic receptor involvement. Brain, behavior, and immunity. 1994b; 8:204-217.

Coussons ME, Dykstra LA, Lysle DT. Pavlovian conditioning of morphine-induced alterations of immune status. Journal of neuroimmunology. 1992; 39:219-230. [PubMed: 1644897]

Davis CN, Tabarean I, Gaidarova S, Behrens MM, Bartfai T. IL-1beta induces a MyD88-dependent and ceramide-mediated activation of Src in anterior hypothalamic neurons. Journal of neurochemistry. 2006; 98:1379-1389. [PubMed: 16771830]

Del-Fava F, Hasue RH, Ferreira JGP, Shammah-Lagnado SJ. Efferent connections of the rostral linear nucleus of the ventral tegmental area in the rat. Neuroscience. 2007; 145:1059-1076. [PubMed: 17270353]

Fanselow MS, Dong HW. Are the dorsal and ventral hippocampus functionally distinct structures? Neuron. 2010; 65:7-19. [PubMed: 20152109]

Fecho K, Maslonek KA, Dykstra LA, Lysle DT. Assessment of the involvement of central nervous system and peripheral opioid receptors in the immunomodulatory effects of acute morphine treatment in rats. Journal of Pharmacology and Experimental Therapeutics. 1996; 276:626-636. [PubMed: 8632330]

Flannery S, Bowie AG. The interleukin-1 receptor-associated kinases: Critical regulators of innate immune signalling. Biochem Pharmacol. 2010; 80:1981-1991. [PubMed: 20599782]

Fuchs RA, Eaddy JL, Su ZI, Bell GH. Interactions of the basolateral amygdala with the dorsal hippocampus and dorsomedial prefrontal cortex regulate drug context-induced reinstatement of 
cocaine-seeking in rats. European Journal of Neuroscience. 2007; 26:487-498. [PubMed: 17650119]

Fuchs RA, Evans KA, Ledford CC, Parker MP, Case JM, Mehta RH, See RE. The role of the dorsomedial prefrontal cortex, basolateral amygdala, and dorsal hippocampus in contextual reinstatement of cocaine seeking in rats. Neuropsychopharmacology: official publication of the American College of Neuropsychopharmacology. 2005; 30:296-309. [PubMed: 15483559]

Goshen I, Kreisel T, Ounallah-Saad H, Renbaum P, Zalzstein Y, Ben-Hur T, Levy-Lahad E, Yirmiya R. A dual role for interleukin-1 in hippocampal-dependent memory processes. Psychoneuroendocrino. 2007; 32:1106-1115.

Green SJ, Mellouk S, Hoffman SL, Meltzer MS, Nacy CA. Cellular mechanisms of nonspecific immunity to intracellular infection: cytokine-induced synthesis of toxic nitrogen oxides from Larginine by macrophages and hepatocytes. Immunol Lett. 1990; 25:15-19. [PubMed: 2126524]

Green SJ, Nacy CA, Schreiber RD, Granger DL, Crawford RM, Meltzer MS, Fortier AH. Neutralization of gamma interferon and tumor necrosis factor alpha blocks in vivo synthesis of nitrogen oxides from L-arginine and protection against Francisella tularensis infection in Mycobacterium bovis BCG-treated mice. Infection and immunity. 1993; 61:689-698. [PubMed: 8423095]

Griffin WS, Stanley LC, Ling C, White L, MacLeod V, Perrot LJ, White CL 3rd, Araoz C. Brain interleukin 1 and S-100 immunoreactivity are elevated in Down syndrome and Alzheimer disease. Proceedings of the National Academy of Sciences of the United States of America. 1989; 86:7611-7615. [PubMed: 2529544]

Guasch RM, Blanco AM, Perez-Arago A, Minambres R, Talens-Visconti R, Peris B, Guerri C. RhoE participates in the stimulation of the inflammatory response induced by ethanol in astrocytes. Experimental cell research. 2007; 313:3779-3788. [PubMed: 17707794]

Hibbs JB Jr, Vavrin Z, Taintor RR. L-arginine is required for expression of the activated macrophage effector mechanism causing selective metabolic inhibition in target cells. J Immunol. 1987; 138:550-565. [PubMed: 2432129]

Hrabak A, Csuka I, Bajor T, Csatary LK. The cytotoxic anti-tumor effect of MTH-68/H, a live attenuated Newcastle disease virus is mediated by the induction of nitric oxide synthesis in rat peritoneal macrophages in vitro. Cancer Lett. 2006; 231:279-289. [PubMed: 16399229]

Huang Y, Smith DE, Ibanez-Sandoval O, Sims JE, Friedman WJ. Neuron-specific effects of interleukin-1beta are mediated by a novel isoform of the IL-1 receptor accessory protein. The Journal of neuroscience: the official journal of the Society for Neuroscience. 2011; 31:1804818059. [PubMed: 22159118]

Hussey HH, Katz S. Infections resulting from narcotic addiction; report of 102 cases. The American journal of medicine. 1950; 9:186-193. [PubMed: 15432465]

Ikemoto S. Dopamine reward circuitry: Two projection systems from the ventral midbrain to the nucleus accumbens-olfactory tubercle complex. Brain Res Rev. 2007; 56:27-78. [PubMed: 17574681]

Karupiah G, Xie QW, Buller RM, Nathan C, Duarte C, MacMicking JD. Inhibition of viral replication by interferon-gamma-induced nitric oxide synthase. Science. 1993; 261:1445-1448. [PubMed: 7690156]

Lasseter HC, Wells AM, Xie XH, Fuchs RA. Interaction of the Basolateral Amygdala and Orbitofrontal Cortex is Critical for Drug Context-Induced Reinstatement of Cocaine-Seeking Behavior in Rats. Neuropsychopharmacology: official publication of the American College of Neuropsychopharmacology. 2011; 36:711-720. [PubMed: 21124303]

Liew FY. Regulation of nitric oxide synthesis in infectious and autoimmune diseases. Immunol Lett. 1994; 43:95-98. [PubMed: 7737695]

Lindgren H, Stenmark S, Chen W, Tarnvik A, Sjostedt A. Distinct roles of reactive nitrogen and oxygen species to control infection with the facultative intracellular bacterium Francisella tularensis. Infection and immunity. 2004; 72:7172-7182. [PubMed: 15557642]

Louria DB, Hensle T, Rose J. The major medical complications of heroin addiction. Annals of internal medicine. 1967; 67:1-22. [PubMed: 5339228] 
Luecken LJ, Lysle DT. Evidence for the involvement of beta-adrenergic receptors in conditioned immunomodulation. Journal of neuroimmunology. 1992; 38:209-219. [PubMed: 1351060]

Luttgens WF. Endocarditis in main line opium addicts; report on 11 cases. Arch Intern Med (Chic). 1949; 83:653-664. [PubMed: 18152229]

Lysle DT, Cunnick JE, Fowler H, Rabin BS. Pavlovian conditioning of shock-induced suppression of lymphocyte reactivity: acquisition, extinction, and preexposure effects. Life Sci. 1988; 42:21852194. [PubMed: 3374253]

Lysle DT, Hoffman KE, Dykstra LA. Evidence for the involvement of the caudal region of the periaqueductal gray in a subset of morphine-induced alterations of immune status. The Journal of pharmacology and experimental therapeutics. 1996; 277:1533-1540. [PubMed: 8667220]

Lysle DT, How T. Heroin modulates the expression of inducible nitric oxide synthase. Immunopharmacology. 2000; 46:181-192. [PubMed: 10741899]

Lysle DT, Ijames SG. Heroin-associated environmental stimuli modulate the expression of inducible nitric oxide synthase in the rat. Psychopharmacology. 2002; 164:416-422. [PubMed: 12457272]

MacMicking JD, Nathan C, Hom G, Chartrain N, Fletcher DS, Trumbauer M, Stevens K, Xie QW, Sokol K, Hutchinson N, et al. Altered responses to bacterial infection and endotoxic shock in mice lacking inducible nitric oxide synthase. Cell. 1995; 81:641-650. [PubMed: 7538909]

Marcinkiewicz J, Chain BM. Differential regulation of cytokine production by nitric oxide. Immunology. 1993; 80:146-150. [PubMed: 8244457]

Maren S, Holt WG. The hippocampus and contextual memory retrieval in Pavlovian fear conditioning. Integr Phys Beh Sci. 1999; 34:123-124.

Mcdonald AJ. Topographical Organization of Amygdaloid Projections to the Caudatoputamen, Nucleus-Accumbens, and Related Striatal-Like Areas of the Rat-Brain. Neuroscience. 1991; 44:15-33. [PubMed: 1722890]

McPherson CA, Aoyama M, Harry GJ. Interleukin (IL)-1 and IL-6 regulation of neural progenitor cell proliferation with hippocampal injury: Differential regulatory pathways in the subgranular zone (SGZ) of the adolescent and mature mouse brain. Brain Behavior and Immunity. 2011; 25:850862 .

Murray HW, Nathan CF. Macrophage microbicidal mechanisms in vivo: reactive nitrogen versus oxygen intermediates in the killing of intracellular visceral Leishmania donovani. J Exp Med. 1999; 189:741-746. [PubMed: 9989990]

Oates JC, Gilkeson GS. The biology of nitric oxide and other reactive intermediates in systemic lupus erythematosus. Clin Immunol. 2006; 121:243-250. [PubMed: 16861040]

Orangio GR, Pitlick SD, Della Latta P, Mandel LJ, Marino C, Guarneri JJ, Giron JA, Margolis IB. Soft tissue infections in parenteral drug abusers. Annals of surgery. 1984; 199:97-100. [PubMed: 6691735]

Paxinos, G.; Watson, C. The rat brain in stereotaxic coordinates. Academic Press; San Diego: 1998.

Phillips RG, Ledoux JE. Lesions of the Dorsal Hippocampal-Formation Interfere with Background but Not Foreground Contextual Fear Conditioning. Learn Memory. 1994; 1:34-44.

Ramirez DR, Bell GH, Lasseter HC, Xie XO, Traina SA, Fuchs RA. Dorsal hippocampal regulation of memory reconsolidation processes that facilitate drug context-induced cocaine-seeking behavior in rats. European Journal of Neuroscience. 2009; 30:901-912. [PubMed: 19712098]

Redish AD. The hippocampal debate: are we asking the right questions? Behavioural brain research. 2001; 127:81-98. [PubMed: 11718886]

Ringwood L, Li L. The involvement of the interleukin-1 receptor-associated kinases (IRAKs) in cellular signaling networks controlling inflammation. Cytokine. 2008; 42:1-7. [PubMed: 18249132]

Ross FM, Allan SM, Rothwell NJ, Verkhratsky A. A dual role for interleukin-1 in LTP in mouse hippocampal slices. Journal of neuroimmunology. 2003; 144:61-67. [PubMed: 14597099]

Rossi GR, Cervi LA, Garcia MM, Chiapello LS, Sastre DA, Masih DT. Involvement of nitric oxide in protecting mechanism during experimental cryptococcosis. Clin Immunol. 1999; 90:256-265. [PubMed: 10080838]

Rothwell NJ. Functions and Mechanisms of Interleukin-1 in the Brain. Trends Pharmacol Sci. 1991; 12:430-436. [PubMed: 1796497] 
Saurer TB, Ijames SG, Lysle DT. Evidence for the nucleus accumbens as a neural substrate of heroininduced immune alterations. The Journal of pharmacology and experimental therapeutics. 2009; 329:1040-1047. [PubMed: 19258519]

Schmid AW, Lynch MA, Herron CE. The effects of IL-1 receptor antagonist on beta amyloid mediated depression of LTP in the rat CA1 in vivo. Hippocampus. 2009; 19:670-676. [PubMed: 19115392]

Schneider H, Pitossi F, Balschun D, Wagner A, del Rey A, Besedovsky HO. A neuromodulatory role of interleukin-1beta in the hippocampus. Proceedings of the National Academy of Sciences of the United States of America. 1998; 95:7778-7783. [PubMed: 9636227]

Simonovska N, Chibishev A, Bozinovska C, Grcevska L, Dimitrovski K, Neceva V. Evaluation of circulating immune complexes and antiphospholipid antibodies (anti beta 2 glycoprotein 1 ) in heroin addicts and their clinical significance. Medicinski arhiv. 2011; 65:324-326. [PubMed: 22299289]

Stofkova A, Skurlova M, Tybitanclova K, Veselsky L, Zelezna B, Jurcovicova J. Relationship among nitric oxide, leptin, ACTH, corticosterone, and IL-1beta, in the early and late phases of adjuvant arthritis in male Long Evans rats. Life Sci. 2006; 79:2486-2491. [PubMed: 16962144]

Szczytkowski JL, Fuchs RA, Lysle DT. Ventral tegmental area-basolateral amygdala-nucleus accumbens shell neurocircuitry controls the expression of heroin-conditioned immunomodulation. Journal of neuroimmunology. 2011; 237:47-56. [PubMed: 21722970]

Szczytkowski JL, Lysle DT. Conditioned effects of heroin on the expression of inducible nitric oxide synthase in the rat are susceptible to extinction and latent inhibition. Psychopharmacology. 2007; 191:879-889. [PubMed: 17211650]

Szczytkowski JL, Lysle DT. Conditioned effects of heroin on proinflammatory mediators require the basolateral amygdala. The European journal of neuroscience. 2008; 28:1867-1876. [PubMed: 18973600]

Szczytkowski JL, Lysle DT. Dopamine D1 receptors within the basolateral amygdala mediate heroininduced conditioned immunomodulation. Journal of neuroimmunology. 2010; 226:38-47. [PubMed: 20605224]

Taylor-Robinson AW, Liew FY, Severn A, Xu D, McSorley SJ, Garside P, Padron J, Phillips RS. Regulation of the immune response by nitric oxide differentially produced by Thelper type 1 and T helper type 2 cells. Eur J Immunol. 1994; 24:980-984. [PubMed: 8149966]

Theodorou S, Haber PS. The medical complications of heroin use. Current opinion in psychiatry. 2005; 18:257-263. [PubMed: 16639149]

Tsai WC, Strieter RM, Zisman DA, Wilkowski JM, Bucknell KA, Chen GH, Standiford TJ. Nitric oxide is required for effective innate immunity against Klebsiella pneumoniae. Infection and immunity. 1997; 65:1870-1875. [PubMed: 9125574]

Tsakiri N, Kimber I, Rothwell NJ, Pinteaux E. Interleukin-1-induced interleukin-6 synthesis is mediated by the neutral sphingomyelinase/Src kinase pathway in neurones. Br J Pharmacol. 2008; 153:775-783. [PubMed: 18059318]

Van Dervort AL, Yan L, Madara PJ, Cobb JP, Wesley RA, Corriveau CC, Tropea MM, Danner RL. Nitric oxide regulates endotoxin-induced TNF-alpha production by human neutrophils. J Immunol. 1994; 152:4102-4109. [PubMed: 8144975]

Vincendeau P, Daulouede S, Veyret B, Darde ML, Bouteille B, Lemesre JL. Nitric oxide-mediated cytostatic activity on Trypanosoma brucei gambiense and Trypanosoma brucei brucei. Experimental parasitology. 1992; 75:353-360. [PubMed: 1426137]

Viviani B, Bartesaghi S, Gardoni F, Vezzani A, Behrens MM, Bartfai T, Binaglia M, Corsini E, Di Luca M, Galli CL, Marinovich M. Interleukin-1beta enhances NMDA receptor-mediated intracellular calcium increase through activation of the Src family of kinases. The Journal of neuroscience: the official journal of the Society for Neuroscience. 2003; 23:8692-8700. [PubMed: 14507968]

Weber A, Wasiliew P, Kracht M. Interleukin-1 (IL-1) pathway. Science signaling. 2010; 3:cm1. [PubMed: 20086235]

Weber RJ, Pert A. The periaqueductal gray matter mediates opiate-induced immunosuppression. Science. 1989; 245:188-190. [PubMed: 2749256] 
Wei XQ, Charles IG, Smith A, Ure J, Feng GJ, Huang FP, Xu D, Muller W, Moncada S, Liew FY. Altered immune responses in mice lacking inducible nitric oxide synthase. Nature. 1995; 375:408411. [PubMed: 7539113]

White AG. Medical disorders in drug addicts. 200 consecutive admissions. JAMA: the journal of the American Medical Association. 1973; 223:1469-1471. [PubMed: 4740030]

Yabuuchi K, Minami M, Katsumata S, Satoh M. Localization of Type-I Interleukin-1 Receptor Messenger-Rna in the Rat-Brain. Mol Brain Res. 1994; 27:27-36. [PubMed: 7877451]

Zhang R, Sun L, Hayashi Y, Liu X, Koyama S, Wu Z, Nakanishi H. Acute p38-mediated inhibition of NMDA-induced outward currents in hippocampal CA1 neurons by interleukin-1beta.

Neurobiology of disease. 2010; 38:68-77. [PubMed: 20060906] 


\section{Highlights}

Overall, the results reported here indicate that IL-1 $\beta$ within the dorsal hippocampus plays a critical role in heroin-induced conditioned immunomodulation. 


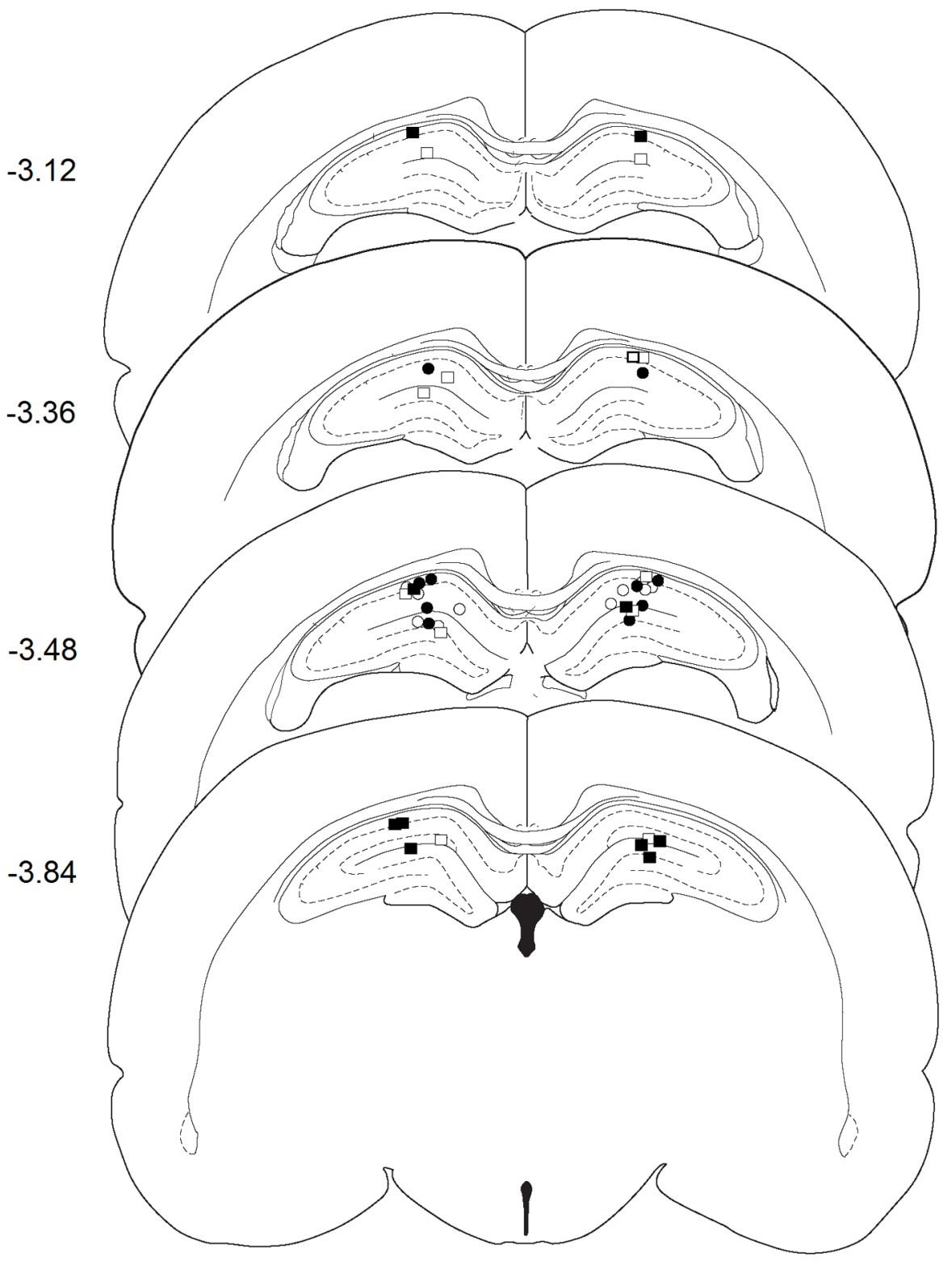

Figure 1.

Injection cannula placement in experiment 1 as verified by light microscopy and mapped onto schematics from the rat brain atlas of Paxinos and Watson (Paxinos and Watson, 1998). Symbols represent the most ventral point of injection cannula tracts for each animal that received bilateral vehicle (Sal) or B/M microinfusions into the $\mathrm{DH}$ following exposure to the previously heroin-paired context (CS) or the home cage (HC). Numbers indicate the distance from bregma in mm. Symbols: $\mathrm{CS}+\mathrm{Sal}$, open squares; $\mathrm{CS}+\mathrm{B} / \mathrm{M}$, filled squares; $\mathrm{HC}+\mathrm{Sal}$, open circles; $\mathrm{HC}+\mathrm{B} / \mathrm{M}$, filled circles 
A

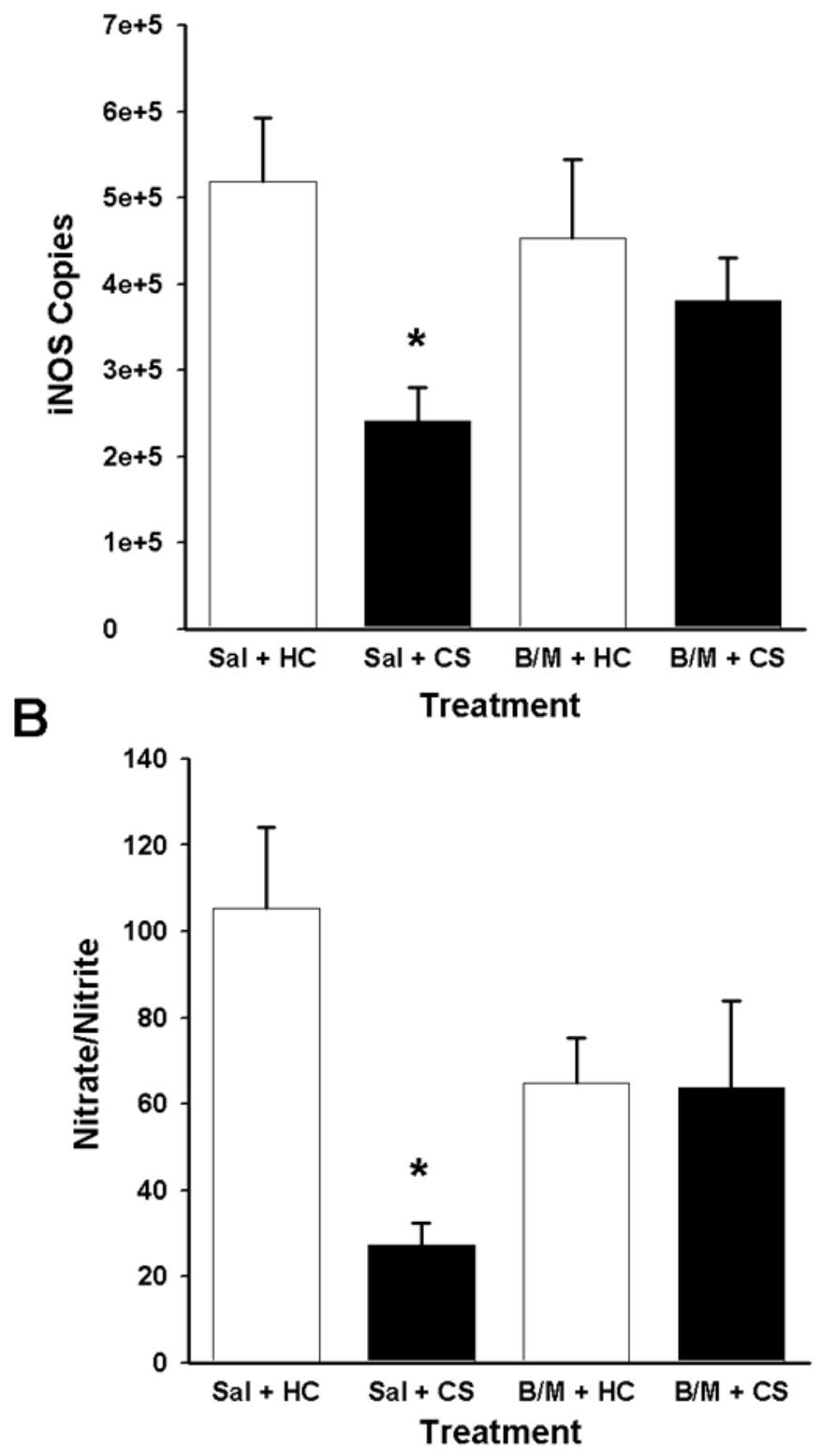

Figure 2.

Effects of GABA agonist-induced inactivation of the DH on indices of LPS-induced nitric oxide production. A: Splenic iNOS mRNA expression (mean copies per $10 \mathrm{ng}$ cDNA + SEM) assessed based on a standard curve using Roche LightCycler software, following bilateral intra-DH administration of vehicle (Sal) or $\mathrm{GABA}_{\mathrm{A} / \mathrm{B}}$ agonists $(\mathrm{B} / \mathrm{M} ; 0.3 / 0.03 \mathrm{nmol}$ per $0.3 \mu \mathrm{l} /$ hemisphere) and exposure to the previously heroin-paired context $(\mathrm{CS})$ or the home cage (HC). B: Plasma nitrate/nitrite levels (mean micromolar concentration of nitrate/ nitrite + SEM) as determined by the Greiss reagent assay. $(*)$ Asterisks indicate significant difference relative to the Sal $+\mathrm{HC}$ group (Tukey test, $\mathrm{p}<0.05$ ). 


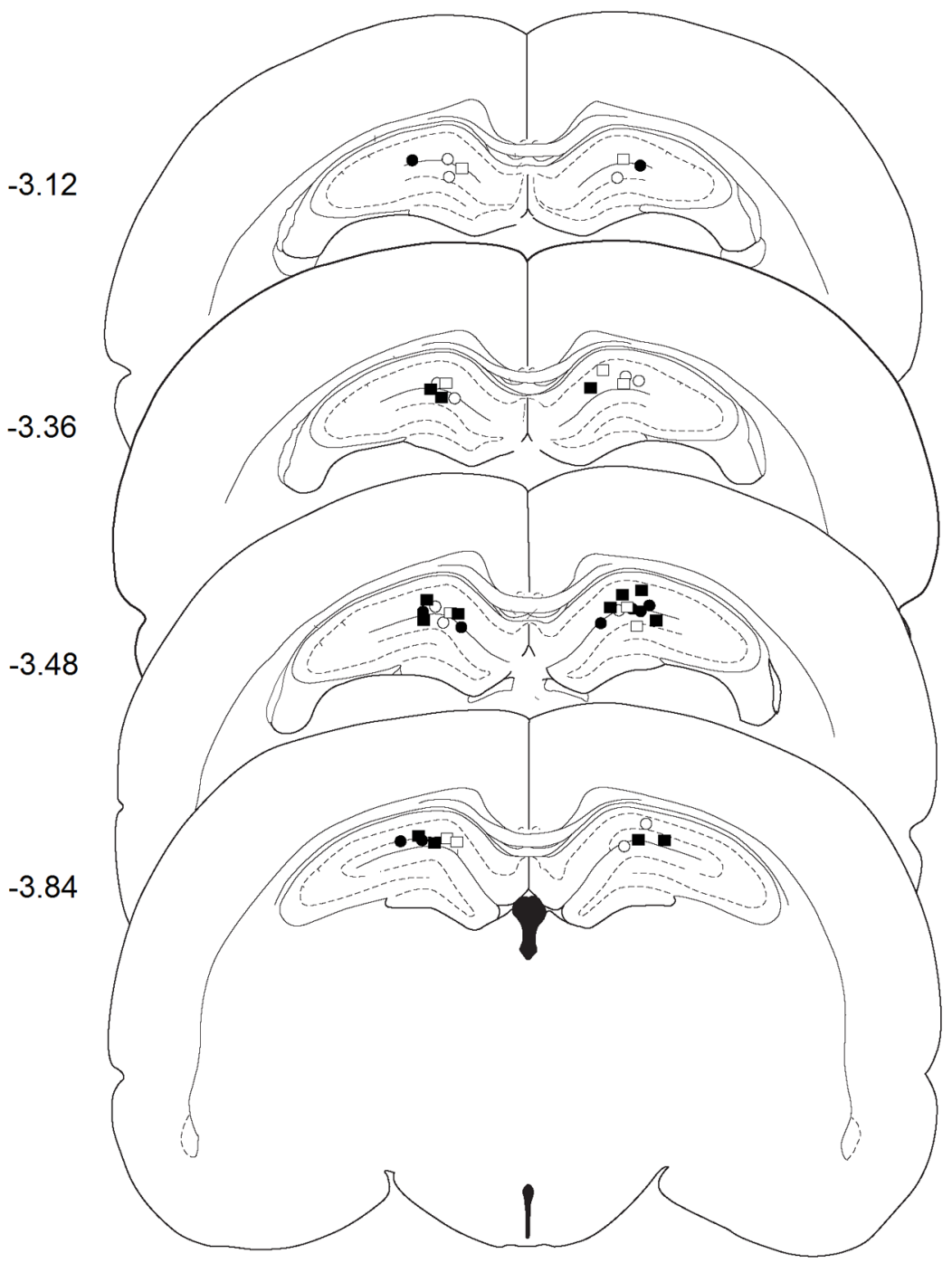

Figure 3.

Injection cannula placement in experiment 2 as verified by light microscopy and mapped onto schematics from the rat brain atlas of Paxinos and Watson (Paxinos and Watson, 1998). Symbols represent the most ventral point of injection cannula tracts for each animal that received bilateral negative control or IL- $1 \beta$ siRNA following exposure to the previously heroin-paired context (CS) or the home cage (HC). Numbers indicate the distance from bregma in mm. Symbols: CS + Neg Con, open squares; CS + siRNA, filled squares; $\mathrm{HC}+$ Neg Con, open circles; $\mathrm{HC}+$ siRNA, filled circles 


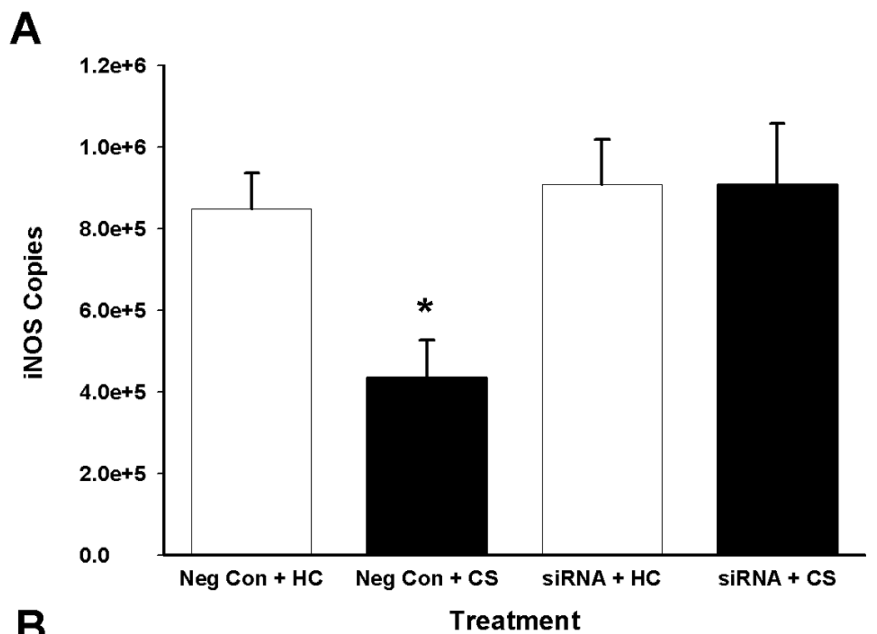

B

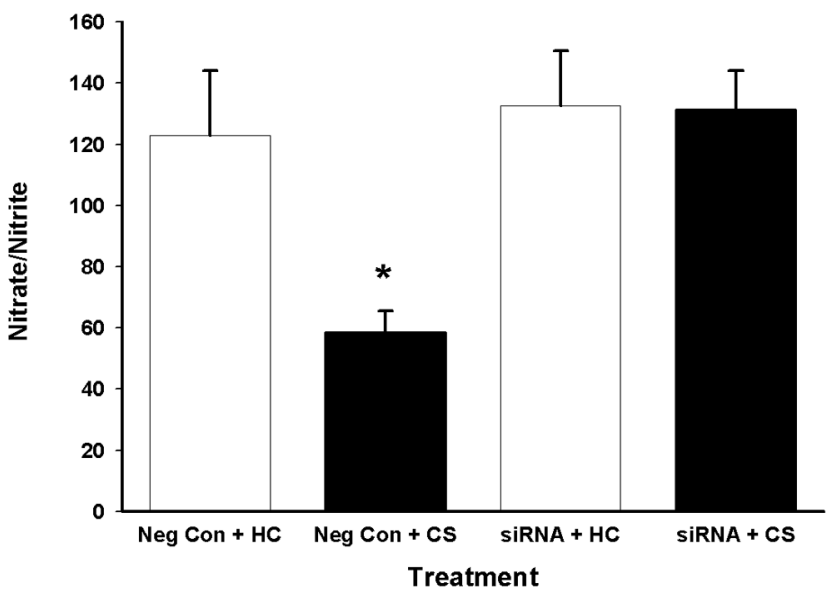

Figure 4.

Effects of IL-1 $\beta$ RNA interference on indices of LPS-induced nitric oxide production. A: Splenic iNOS mRNA expression (mean copies per $10 \mathrm{ng}$ cDNA + SEM) assessed following bilateral intra-DH administration of negative control or IL- $1 \beta$ siRNA (both $5.6 \mathrm{pmol} / 0.7 \mu \mathrm{l} /$ hemisphere) and exposure to the previously heroin-paired context (CS) or the home cage (HC). B: Plasma nitrate/nitrite levels (mean micromolar concentration of nitrate/nitrite + SEM) as determined by the Greiss reagent assay. (*) Asterisks indicate significant difference relative to the Saline $+\mathrm{HC}$ group (Tukey test, $\mathrm{p}<0.05$ ). 


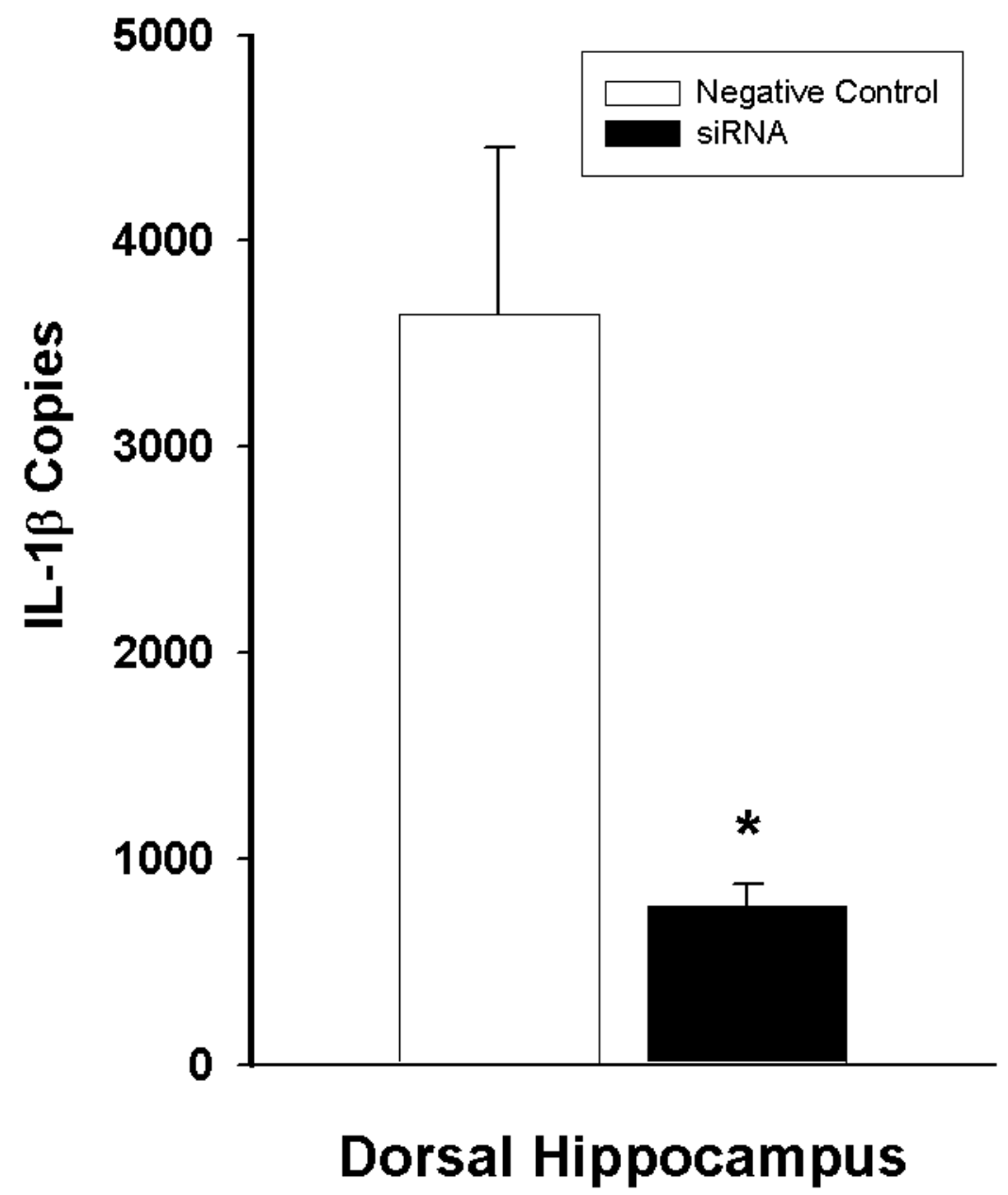

Figure 5.

Effects of the IL-1 $\beta$ siRNA manipulation on LPS-induced IL-1 $\beta$ mRNA expression (mean copies per $10 \mathrm{ng}$ cDNA + SEM). Negative control or IL-1 $\beta$ siRNA (both $5.6 \mathrm{pmol} / 0.7 \mu \mathrm{l} /$ hemisphere) was administered into the DH $4 \mathrm{~h}$ prior to LPS administration, and DH tissue was harvested $4 \mathrm{~h}$ thereafter. (*) Asterisk indicates a significant difference relative to negative control (Student's t-test, $\mathrm{p}<0.05$ ). 